Pak. j. sci. ind. res. Ser. B: biol. sci. 201558 (3) 126-131

\title{
Seasonal Variation in Foliage Quality of Acacia modesta Wall. Growing in Different Ecological Zones of Pothwar, Pakistan
}

\author{
Muhammad Yasin ${ }^{\mathrm{a} *}$, Muhammad Mehmood-ul-Hassan ${ }^{\mathrm{a}}$, Rizwan Ahmad ${ }^{\mathrm{a}}$, Atiya Azim ${ }^{\mathrm{b}}$, \\ Irshad Ahmad Khanc and Muhammad ArshadUllah ${ }^{a}$ \\ ${ }^{a}$ LRRI, National Agricultural Research Centre, Park Road, Islamabad, Pakistan \\ ${ }^{\mathrm{b}}$ Animal Nutrition, National Agricultural Research Centre, Park Road, Islamabad, Pakistan \\ ${ }^{\mathrm{c}}$ Department of Forestry and Range Management, Arid Agriculture University, Rawalpindi, Pakistan
}

(received August 7, 2014; revised August 6, 2015; accepted August 28, 2015)

\begin{abstract}
In this study, the seasonal variability in nutritive value of foliage of Acacia modesta Wall. was evaluated. Leaves and twigs of $A$. modesta were collected from low, medium and high rainfall Pothwar regions of Pakistan i.e. Rawalpindi, Jhelum and Talagang during spring, summer and fall seasons. The forage samples were analysed for dry matter (DM), crude protein (CP), ether extract (EE), ash content (AC), crude fibre (CF), acid detergent fibre (ADF), neutral detergent fibre (NDF) and acid detergent lignin (ADL). Dry matter varied from 44.3 to $65.0 \%$ and was significantly higher during fall than spring and summer season at all three sites. Talagang site had the highest dry matter followed by Jhelum and Rawalpindi sites. The CP was in the range of 14.4-17.4\%. The CP was in order of spring, summer and fall season. Rawalpindi and Jhelum had the highest CP (16.4\%) followed by Talagang site (15.9\%). Ash content and ether extract (EE) ranged from 5.8 to $10.4 \%$ and 1.1 to $3.2 \%$ in season and site interaction. Crude fibre (CF) value ranged from 19.9 to $27.6 \%$ and was significantly higher in fall than spring and summer. The highest CF (24.6\%) was found at Rawalpindi followed by Jhelum (21.6\%) and Talagang (22.1\%). Seasonal variation in ADF and NDF ranged from 34.4 to $38.5 \%$ and 50.5 to $56.5 \%$, respectively. The ADF and NDF were lower in summer season than in spring and fall seasons. ADF was the highest $(36.4 \%)$ at Jhelum followed by Talagang (36.3\%) and Rawalpindi site (35.9\%). The ADL ranged from 9.8 to $13.4 \%$ and was higher in summer than in spring and fall seasons. Based on chemical composition, it was concluded that $A$. modesta foliage contained high nutritional values and can be fed to ruminants as supplement to lowquality feeds particularly during the dry season.
\end{abstract}

Keywords: seasonal variation, foliage quality, Acacia modesta, nutritive value

\section{Introduction}

Pothwar is a semi-arid region of Pakistan with hot summer and cold winter and with a short dry season early in the summer. Scarcity and fluctuation in quantity and quality of the year-round supply of fodder due to seasonal variation are major constraints of the area (Noor, 1989). This fluctuation in quality and quantity can be controlled through supplementation of foliage trees such as Leucaena leucocephala, Acacia modesta, Ziziphus mauritiana etc. in ruminant diets which can improve the utilisation of low quality roughages mainly by supplying protein to rumen microbes (Charbonneau et al., 2007). Several shrubs in the dry areas have potential as stock-feed and for re-vegetation of degraded rangelands, but their quantitative data on their fodder yield and quality are scanty (Imtiaz et al., 2014).

Acacia modesta Wall. is a valuable browse shrub for Pothwar because of its adaptation and productivity in

Author for correspondence: E-mail: yasinhdr@yahoo.com dry to wet, sandy to calcareous and acidic soils (Sher et al., 2012). The plant has common uses as fuel wood and fodder and specific medicinal uses like remedy of mouth ulcer, used as tooth brushes for cleaning and protection of teeth, bark is used in gastric pains, skin diseases and has potential anti-bacterial and antimicrobial activity (Bashir et al., 2012). It is relished by all species of livestock due to palatability and nutritional values. It is a semi evergreen tropical legume tree, commonly known as 'Phulai' in Pothwar (Noor, 1989). It is a fast growing tree in its early age and grows well within the range of 250-1350 mm annual rainfall; temperatures of $40{ }^{\circ} \mathrm{C}$ to below zero (Baquar, 1995). It is strong light demander and fairly drought resistant and can grow in barren land and eroded sites but grows much better in deep soil of Pothwar which is classified as an important component of subtropical dry evergreen forest (Khan and Khan, 2000).

Rawalpindi, Jhelum and Talagang cities are main districts of Pothwar, Pakistan. Total precipitation in spring 
(January-April), summer (May-August), and fall (Septemper-December) seasons at Rawalpindi region was 252,889 and $179 \mathrm{~mm}$, at Jhelum region 198, 409 and $144 \mathrm{~mm}$ and at Talagang region 147, 390 and 70 $\mathrm{mm}$, respectively (Table 1 ) during the study year.

Acacia modesta Wall. has rounded bushy crown comprising of drooping branchlets and feathery foliage. It sheds leaves in winter and new leaves appear in early spring. The pods ripen in autumn and remain on tree for a long time from April to June (Alvi and Sharif., 1995). It is small or medium size deciduous tree and produces highly valuable and nutritious forage for sheep, goats and cattle for the production of milk and meat (Kafeel et al., 2010; Khan and Khan, 2000).

Information of seasonal variation provides a guideline for utilization of forage for optimum use (FAO, 1987). A. modesta Wall. is very important forage in rangeland of Pothwar area of Pakistan. A little knowledge about seasonal variation in forage quality of the tree is available in literature. Thus, the present study was designed to evaluate the forage quality of $A$. modesta Wall. in different seasons in Pothwar.

\section{Materials and Methods}

Sample collection: Five $A$. modesta trees were sampled at random from $200 \mathrm{~m}^{2}$ area of each rangeland of Rawalpindi, Jhelum and Talagang districts of Pothwar in three different seasons i.e., spring, summer and fall. Samples of leaves and twigs were harvested from branches at the height up to $5 \mathrm{ft}$ (the normal height range of animal browsing fodder trees).

Sample preparation and analysis. The samples were packed in plastic bags to conserve the moisture and brought to Animal Nutrition Laboratory, NARC, Islamabad to determine the fresh weight of the samples. The samples were then washed with de-ionised, distilled water, oven dried at $70{ }^{\circ} \mathrm{C}$ till constant weight, ground in plant crusher and stored for analysis. The samples were analysed for dry matter (DM), crude protein $(\mathrm{CP})$, ether extract (EE) and crude fibre (CF) using standard methods as described in AOAC (1990) and for acid detergent fibre (ADF), neutral detergent fibre (NDF) and acid detergent lignin (ADL) according to the procedures described by Van Soest et al. (1991).

Table 1. Total monthly/seasonal rainfall and average temperature for different ecological zones of Pothwar during the foliage sampling period (2008)

\begin{tabular}{|c|c|c|c|c|c|c|c|c|c|}
\hline \multirow[b]{3}{*}{ Month/season } & \multicolumn{3}{|c|}{ Rawalpindi } & \multicolumn{3}{|c|}{ Jhelum } & \multicolumn{3}{|c|}{ Talagang } \\
\hline & \multirow{2}{*}{$\begin{array}{l}\text { Rainfall } \\
(\mathrm{mm})\end{array}$} & \multicolumn{2}{|c|}{ Temperature ${ }^{\circ} \mathrm{C}$} & \multirow{2}{*}{$\begin{array}{l}\text { Rainfall } \\
(\mathrm{mm})\end{array}$} & \multicolumn{2}{|c|}{ Temperature ${ }^{\circ} \mathrm{C}$} & \multirow{2}{*}{$\begin{array}{l}\text { Rainfall } \\
(\mathrm{mm})\end{array}$} & \multicolumn{2}{|c|}{ Temperature ${ }^{\circ} \mathrm{C}$} \\
\hline & & Max. & Min. & & Max. & Min. & & Max. & Min. \\
\hline January & 110.1 & 15.2 & 3.4 & 59.3 & 17.2 & 3.7 & 44.4 & 14.2 & 2.2 \\
\hline February & 41.8 & 19.3 & 4.9 & 20.4 & 21.5 & 7.1 & 36.2 & 18.9 & 5.7 \\
\hline March & 19.1 & 29.8 & 11.8 & 7.0 & 31.4 & 15.0 & 0.1 & 30.0 & 13.3 \\
\hline April & 81.0 & 29.7 & 15.8 & 111.0 & 32.0 & 18.0 & 66.3 & 29.9 & 15.3 \\
\hline \multicolumn{10}{|l|}{ Spring } \\
\hline (Jan.-April) & 252.0 & 23.5 & 9.0 & 197.7 & 25.5 & 11.0 & 147.0 & 23.3 & 9.1 \\
\hline May & 10.1 & 36.9 & 20.7 & 36.5 & 37.8 & 23.5 & 55.2 & 37.3 & 31.8 \\
\hline June & 225.2 & 35.6 & 22.3 & 184.8 & 35.5 & 25.7 & 215.8 & 35.4 & 23.2 \\
\hline July & 432.5 & 35.1 & 22.8 & 120.6 & 34.8 & 25.6 & 76.5 & 34.9 & 24.4 \\
\hline August & 221.0 & 33.3 & 23.0 & 66.6 & 34.8 & 25.9 & 42.6 & 34.4 & 24.2 \\
\hline \multicolumn{10}{|l|}{ Summer } \\
\hline (May-Aug.) & 888.8 & 35.2 & 22.2 & 408.5 & 35.7 & 25.2 & 390.1 & 35.5 & 25.9 \\
\hline September & 65.8 & 32.9 & 19.7 & 65.3 & 34.3 & 23.4 & 12.6 & 34.1 & 20.6 \\
\hline October & 24.0 & 31.0 & 15.4 & 24.0 & 32.9 & 19.3 & 8.0 & 32.8 & 19.3 \\
\hline November & 18.0 & 25.2 & 8.2 & 0.2 & 28.1 & 11.1 & 0.0 & 26.2 & 10.3 \\
\hline December & 71.5 & 20.8 & 5.5 & 54.0 & 23.0 & 8.6 & 49.4 & 20.4 & 7.1 \\
\hline \multicolumn{10}{|l|}{ Fall } \\
\hline (Sep.-Dec.) & 179.3 & 27.5 & 12.2 & 143.5 & 29.6 & 15.6 & 70.0 & 28.4 & 14.3 \\
\hline
\end{tabular}

Source: National Agromet Centre, Pakistan Meteorological Department, Islamabad, Pakistan. 
Statistical analysis. The data was analysed statistically using completely randomised block design (CRBD) and the means obtained were compared by Duncan's Multiple Range Test (DMRT) at 5\% level of significance (Lamers and Khamzina, 2010; Douglas, 2009).

\section{Results and Discussion}

The results showed that the range of value varied from 52.7 to $63.7 \%$ of dry matter (DM). The DM was significantly higher during fall and spring than summer season at all the sites (Table 2). Among the sites, 56.6\% DM of forage at Talagang was the highest followed by $53.9 \%$ at Jhelum and $52.8 \%$ at Rawalpindi site (Table 2). Among the seasons, the highest DM (63.7\%) was found in fall season followed by spring (52.7\%) and summer $(46.9 \%)$ as presented in Table 2 . The results were similar to the findings of Sana-ul-Haq et al. (2011) and El-Toukhy and Ahmed (2005), who observed in an experiment that the highest value of forage dry matter was obtained from plants browsed during the dry season.

Crude protein was in the range of $15.2-17.1 \%$. The $\mathrm{CP}$ was significantly higher during spring than summer and fall (Table 2). Among the sites, the CP (16.4\%) at Rawalpindi and Jhelum sites was found higher than $15.9 \%$ at Talagang site (Table 2). Among the seasons, the $\mathrm{CP}(17.1 \%)$ was the highest during spring followed by $16.5 \%$ in summer and $15.2 \%$ in fall (Table 2 ). Increase in CP can be attributed to suitable soil temperature and moisture content in spring as compared to fall (Evitayani et al., 2006).

Among the samples, the ash content value ranged from 6.2 to $9.8 \%$ (Table 2). The ash content $(9.8 \%$ ) was significantly the highest at Rawalpindi site during summer and the lowest $(6.2 \%)$ at Talagang site during fall season. Among the sites, ash content (8.4\%) was found higher at Rawapindi than the value (7.9) at Jhelum and Talagang (Table 2). Among the seasons, ash content $(9.8 \%)$ was the highest in summer followed by spring $(8.2 \%)$ and $6.2 \%$ in fall season (Table 2) confirmed the earlier observations of Papanastasis et al. (2008).

Relatively, a narrower range of $1.5-2.7 \%$ was found in ether extract (EE) and the highest EE (2.7\%) was observed during summer and the lowest EE $(1.5 \%)$ was found during fall season at Rawalpindi site (Table 2). Among the sites, 2.3\% EE was found significantly the highest at Talagang followed by $2.1 \%$ at Rawalpindi and $1.9 \%$ at Jhelum (Table 2). Among the seasons, EE $(2.7 \%)$ was the highest in summer followed by spring $(2.2 \%)$ and fall (1.5\%). Increase in EE could be attributed to desirable soil temperature, rainfall in spring and summer as compared to fall. The results are in strong agreement with the findings of Hashmi and Waqar (2014) and Sunil et al. (2003) who reported that EE was higher in wet season in different plants than in dry season.

Crude fibre values varied between 20.6 and 25.5\%. Contrary to EE, the highest CF (25.5\%) was found at Rawalpindi during fall and the lowest (20.6\%) during summer at Jhelum (Table 2). Among the sites, Rawalpindi had statistically higher (24.6\%) than Jhelum (21.6\%) and Talgang (22.1\%) as presented in Table 2. Among the season, CF $(25.5 \%)$ was the highest in fall followed by spring $(22.3 \%)$ and summer $(20.6 \%)$. Increase in the $\mathrm{CF}$ in fall season could be attributed to most probably low rainfall and low soil and atmospheric temperatures and fallen leaves as compared to summer season. All of them are the possible factors which contribute to the increase in CF during fall. The results are quite similar to the findings of Evitayani et al. (2006).

Among the samples, nitrogen free extract value ranged from 48.3 to $52.2 \%$. The NFE was the highest in spring and fall at Talagang site and the lowest in Rawalpindi

Table 2. Site and seasonal variation in proximate composition (\%) of foliage

\begin{tabular}{|c|c|c|c|c|c|c|c|c|}
\hline \multirow[t]{2}{*}{ Composition } & \multicolumn{3}{|c|}{ Site } & \multirow[t]{2}{*}{$\operatorname{LSD}_{(0.05)}$} & \multicolumn{3}{|c|}{ Season } & \multirow[t]{2}{*}{$\operatorname{LSD}_{(0.05)}$} \\
\hline & Rawalpindi & Jhelum & Talagang & & Spring & Summer & Fall & \\
\hline Dry matter (DM) & $52.8^{\mathrm{c}}$ & $53.9^{\mathrm{b}}$ & $56.6^{\mathrm{a}}$ & 0.96 & $52.7^{\mathrm{b}}$ & $46.9^{\mathrm{c}}$ & $63.7^{\mathrm{a}}$ & 0.96 \\
\hline Crude protein $(\mathrm{CP})$ & $16.4^{\mathrm{a}}$ & $16.4^{\mathrm{a}}$ & $15.9^{b}$ & 0.40 & $17.1^{\mathrm{a}}$ & $16.5^{\mathrm{b}}$ & $15.2^{\mathrm{c}}$ & 0.40 \\
\hline Ash content & $8.4^{\mathrm{a}}$ & $7.9^{b}$ & $7.9^{b}$ & 0.23 & $8.2^{\mathrm{b}}$ & $9.8^{\mathrm{a}}$ & $6.2^{\mathrm{c}}$ & 0.23 \\
\hline Ether extract (EE) & $2.1^{\mathrm{b}}$ & $1.9^{\mathrm{c}}$ & $2.3^{\mathrm{a}}$ & 0.07 & $2.2^{\mathrm{b}}$ & $2.7^{\mathrm{a}}$ & $1.5^{\mathrm{c}}$ & 0.07 \\
\hline Crude fibre (CF) & $24.6^{\mathrm{a}}$ & $21.6^{\mathrm{b}}$ & $22.1^{\mathrm{b}}$ & 0.67 & $22.3^{b}$ & $20.6^{\mathrm{c}}$ & $25.5^{\mathrm{a}}$ & 0.67 \\
\hline Nitrogen free extract (NFE) & $48.3^{b}$ & $52.2^{\mathrm{a}}$ & $51.8^{\mathrm{a}}$ & 0.61 & $50.2^{b}$ & $50.4^{\mathrm{b}}$ & $51.7^{\mathrm{a}}$ & 0.61 \\
\hline
\end{tabular}

Nitrogen free extract $=100-(\mathrm{CP}+\mathrm{CF}+\mathrm{EE}+$ ash $)$; Values sharing the same letter(s) do not differ significantly at $5 \%$ by DMRT. 
site during spring season (Table 2). Among the sites, NFE values were $52.2 \%$ at Jhelum, $51.8 \%$ at Talagang and $48.3 \%$ at Rawalpindi and the differences were non-significant (Table 2). Similarly, statistically significant differences were found in NFE (51.7\%) in fall and spring $(50.2 \%)$ but significantly lower in summer $(50.4 \%)$ (Table 2). Increase in NFE can be attributed to low rain fall and low soil and atmospheric temperatures during fall and spring seasons as compared to summer season. The results are in close conformity with the findings of Evitayani et al. (2006) who investigated that in general NFE was lower in the rainy season than in the dry season.

Among the samples, acid detergent fibre (ADF) value ranged from 34.0 to $38.9 \%$. The $\mathrm{ADF}(38.9 \%)$ was significantly higher in spring at Talagang site than $34.0 \%$ at Jhelum site in summer season (Fig. 1). Among the sites, $36.4 \% \mathrm{ADF}$ at Jhelum was significantly higher than $36.3 \%$ at Talagang and $35.9 \%$ at Rawalpindi. Among the seasons, $38.5 \%$ ADF in spring was the highest followed by $35.8 \%$ in fall season and $34.4 \%$ in summer (Fig. 1). Increase in ADF in fall and spring can be attributed to low rain fall, low soil and atmospheric temperatures and fallen leaves as compared to summer season. The results are in close conformity with the findings of Hashmi and Waqar (2014) and Evitayani et al. (2006) who investigated that in general, ADF was lower in the rainy season than in the dry season.

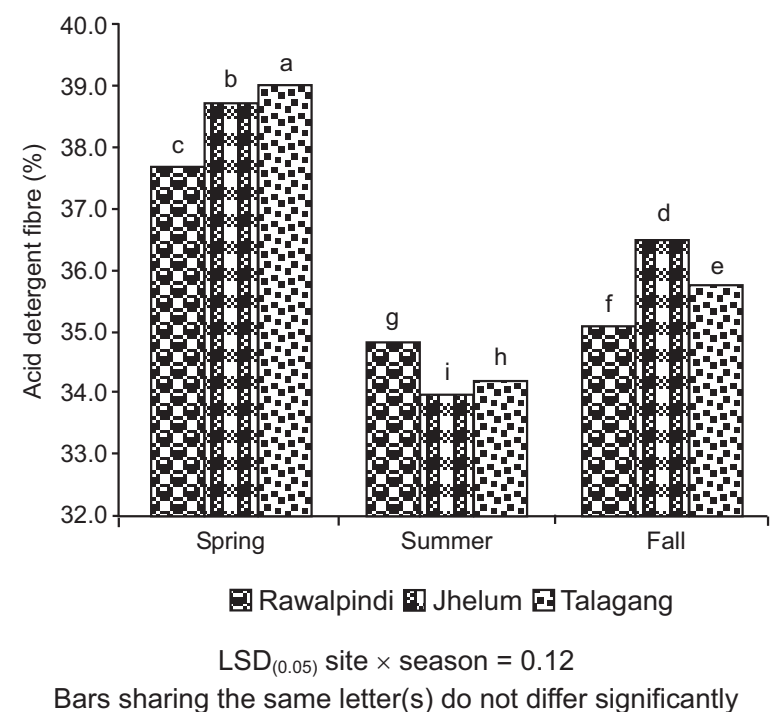

Fig. 1. Effect of site and season interaction on ADF (\%) of foliage of A. modesta in different ecological zones of Pothwar.
Among the samples, neutral detergent fibre (NDF) was in the range of $47.4-61.2 \%$. The highest $61.2 \%$ NDF was in fall season at Rawalpindi and the lowest (47.4\%) during summer at Jhelum (Fig. 2). Further 58.1\% NDF at Rawalpindi was the highest followed by $53.8 \%$ at Talagang site and $51.8 \%$ at Jhelum (Fig. 2). Among the seasons, $56.6 \%$ NDF in spring and fall were the same and significantly higher than (50.5\%) during summer. Increase in the value of NDF in fall and spring season could be attributed to low rain fall, low soil and atmospheric temperatures and fallen leaves in fall as compared to summer season. Evitayani et al. (2006) gave similar views that in general, NDF was lower in the rainy season than in the dry season.

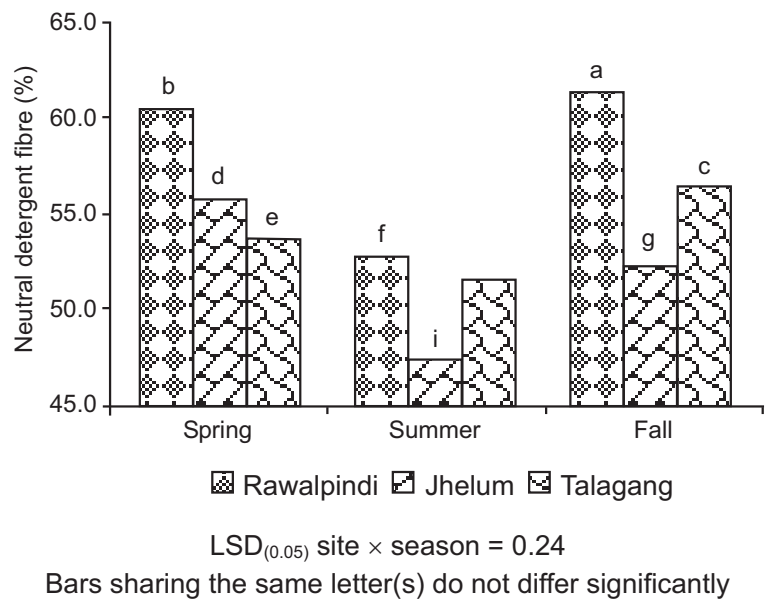

Fig. 2. Effect of site and season interaction on Neutral detergent fibre (\%) of foliage of A. modesta in different ecological zones of Pothwar.

Acid detergent lignin (ADL) ranged from 3.4 to $9.8 \%$. The ADL was significantly the highest $(13.4 \%)$ in summer and the lowest (9.6\%) in spring at Talagang (Fig. 3). Among the sites, $11.4 \%$ ADL at Rawalpindi site was higher than $11.3 \%$ at Jhelum and $11.2 \%$ at Talagang. Among the seasons, the highest ADL (12.6\%) was found in summer followed by $11.0 \%$ in spring and $10.3 \%$ in fall (Fig. 3). Increase in ADL in summer can be attributed to old leaves, and high atmospheric temperature and higher growth of twigs due to high rain fall. The results are not in agreement with the findings of Evitayani et al. (2006) who claimed that in general, ADL was lower in the rainy season than in the dry season. 


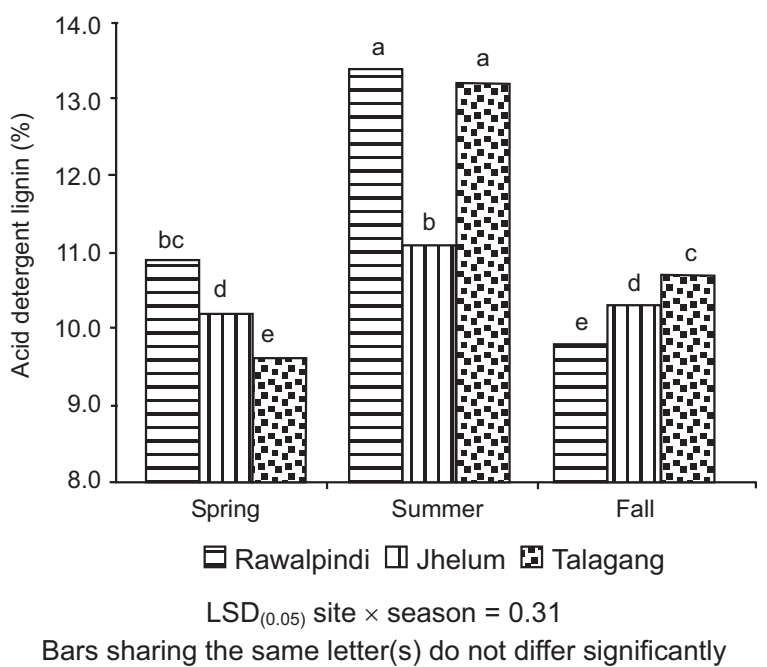

Fig. 3. Effect of site and season interaction on acid detergent lignin (\%) of foliage of $A$. modesta Wall. in different ecological zones of Pothwar.

Zhou et al. (2011) evaluated the nutritive value of tropical legume shrub species Cratylia argentea, Leucaena leucocephala, Flemingia macrophylla, Cajanus cajan, Dendrolobium triangular, Cassia didymobotrya, Cassia bicapsularis and Acacia farnesiana in Hainan province, China. The $\mathrm{CP}$ contents of legume shrubs ranged from $13.43 \%$ (D. triangulare) to $18.44 \%$ (C. argentea). The ADF and NDF contents varied between $20.73 \%$ (S. didymobotrya) to $48.61 \%$ (D. triangulare) and $21.11 \%$ (S. didymobotrya) to $55.27 \%$ (D. triangulare), respectively.

The nutritive evaluation of mixture of fresh acacia and atriplex (1:1, FAA) and mixture of silages of acacia and atriplex (1:1, AAS), revealed that the mixing acacia with atriplex in fresh form could be formed good quality roughage and alternative animal feed resource for ruminant feeding especially in the dry season or when roughage source availability was low (El-Waziry, 2007).

Evaluation of the forage quality of browse species in southern Europe, particularly in areas with dry to semi dry Mediterranean climates, indicated that the species alleviate feed shortages in winter and especially in summer, when grassland growth is limited or dormant due to unfavourable weather conditions and observed that in general, they have a low content of $\mathrm{CP}$ and are high in fibre and ash. The nutrients vary greatly according to season, with a higher concentration of fibre and ash and a lower content of CP during summer (Papanastasis et al., 2008).
In a study, effect of native pasture hay (NPH), sun-dried Acacia nilotica (NLM), A. polyacantha (PLM) and Leucaena leucocephala (LLM) supplementation was investigated on growth performance of goats. The results indicated that supplementation of the animals with browse resulted to $(\mathrm{P}<0.05)$ higher average daily weight gain (ADG) than the animals fed on NPH. Higher ADG was due to LLM and NLM browse supplementation (Rubanza et al., 2007).

Ruminal bacteria or microbes provide the primary source of protein that will be used by the animal, known as microbial crude protein. (Griswold et al., 1996). Beneficial microbes live in the large compartment of the ruminant stomach known as the rumen and are capable of degrading fibrous components like cellulose into valuable nutrients for the animal such as fatty acids. Poor quality forages fed to ruminants with energy and protein supplements increase feed intake and digestibility through the effect on rumen fermentation status and support optimum activity of the rumen microbes (Fujihara et al., 2003).

The results of proximate parameters of forage of A. modesta showed that the forages had higher crude protein content (15.2-16.5\% of DM) and low to moderate values of ash, ether extract, nitrogen-free extract (Table 2) and cell wall parameters (Fig. 1-3). Forage quality parameters such as dry matter, crude protein, ash content, ether extract, and nitrogen free extract of A. modesta Wall. were found better in summer (wet) season. Cell wall parameters such as neutral detergent fibre and acid detergent fibre were found higher in spring and fall (dry) season. The study might be helpful to explore the potential to supply sufficient dry matter rich in protein especially as supplements to low-quality feeds in the lean period for the ruminants particularly during the dry season when no other green fodder is available, so it must be integrated into the rangelands in Pothwar to overcome the feed scarcity particularly in hottest summer and coldest winter months.

\section{References}

Alvi, A.S., Sharif, M. 1995. Arid zone agriculture and research in Pakistan. Progressive Farming, 15: 5-12.

AOAC, 1990. Official Methods of Analysis. Association of Official Analytical Chemists, 684 pp., $15^{\text {th }}$ edition, Washington D.C., USA.

Baquar, S.R. 1995. Trees of Pakistan. Their Natural History Characteristics and Utilization. 634 pp., Royal Book Company, Karachi, Pakisktan. 
Bashir, S., Erum, A., Kausar, R., Saleem, U., RuqiaTulain, U., Alamgeer, 2012. Antimicrobial activity of some ethno-medicinal plants used in Pakistan. Research in Pharmacy, 2: 42-45.

Charbonneau, E., Chouinard, P.Y., Allard, G., Lapierre, H., Pellerin, D. 2007. Milk from forage as affected by rumen degradable protein and corn grinding when feeding corn- and alfalfa silage-based diets. Journal of Dairy Science, 90: 823-832.

Douglas, C.M. 2009. The two factor factorial design. In: Design and Analysis of Experiments, 166 pp., $8^{\text {th }}$ edition, Jhon Wiley \& Sons Inc., 111 River Street, Hoboken, USA.

El-Toukhy, S.A., Ahmed, K.M. 2005. Response of halophyte fodder shrubs to cutting intervals and organic manure application. Egyptian Journal of Agronomy, 27: 71-80.

El-Wazriry, A.M. 2007. Nutritive value assessment of ensiling or mixing Acacia and Atriplex using in vitro gas production technique. Research Journal of Agriculture and Biological Science, 3: 605-614.

Evitayani, W.L., Fariani, A., Ichinohe, A., Hayashida, T., Razak, M., Fujihara, T. 2006. Macro mineral distribution of forages in South Sumatra during rainy and dry seasons. Journal of Food, Agriculture and Environment, 4: 155-160.

FAO, 1987. Pakistan's Experience in Rangeland Rehabilitation and Improvement, 70 pp., Food and Agriculture Organization of the United Nations.

Fujihara, T., Ichinohe, T., Waley, L., Orden, E.A., Abdulrazak, S.A. 2003. Improvement of feeding value of low quality roughages to enhance ruminants production in tropical regions. Bulletin of Faculty of Life and Environmental Science, Shimane University, Japan, 8: 29-38.

Griswold, K.E., Hoover, W.H., Millar, T.K., Thayne, W.V. 1996. Effect of form of nitrogen on growth of ruminal microbes in continuous culture. Journal of Animal Science, 74: 483-491.

Hashmi, M.M., Waqar, K. 2014. Nutritional evaluation of Grewia optiva and Grewia populifolia in different seasons and sites of Chakwal district in Pakistan. European Academic Research, 2: 5047-5057.

Kafeel, A., Zafar, I.K., Muhammad, I., Muhammad, A., Mumtaz, H. 2010. Evaluation of nutritional composition of plant species of Soone valley in Punjab. Pakistan Journal of Plant Nutrition, 4: 496-517.

Khan, N., Khan, J.A. 2000. Pothwar scrub ranges. In: Rangeland Management in Pakistan, pp. 16-17,
Reproduced by National Book Foundation of Pakistan.

Lamers, J.P., Khamzina, A. 2010. Seasonal quality profile and production of foliage from trees grown on degraded cropland in arid Uzbekistan, Central Asia. Journal of Animal Physiology and Animal Nutrition, 94: e77-e85.

Noor, M. 1989. Rangeland Management in Pakistan. ICIMOD, Senior Fellowship Series No.1, 193 pp., International Centre for Integrated Mountain Development, Kathmandu, Nepal.

Papanastasis, V.P., Yiakoulaki, M.D., Decandia, M., Dini-Papanastasi, O. 2008. Integrating woody species into livestock feeding in the Mediterranean areas of Europe. Animal Feed Science and Technology, 140: $1-17$.

Qamar, I.A., Ahmad, M., Riaz, G., Khan, S. 2014. Performance of summer forage legumes and their residual effect on subsequent oat crop in subtropical sub humid Pothwar, Pakistan. Pakistan Journal of Agricultural Research, 27: 14-20.

Rubanza, C.D.K., Shem, M.N., Bakengesa, S.S., Ichinohe, T., Fujihara, T. 2007. Effects of Acacia nilotica, A. polyacantha and Leucaena leucocephala leaf meal supplementation on performance of small East African goats fed native pasture hay basal forages. Small Ruminants Research, 70: 165-173.

Sana-ul-Haq, Mirza, S.N., Nizami, S.M., Chaudhry, A.K., Khan, I.A., Qureshi, R. 2011. Vegetation analysis and winter season carrying capacity of sub-tropical, sub humid rangelands of Dhrabi watershed, Pakistan. Pakistan Journal of Botany, 43: 1669-1672.

Sher, H., Aldosari, A., Ahmad, S. 2012. Ethnoecological appraisal of Acacia modesta Wall. common tree of dry ecosystem in Pakistan. African Journal of Agricultural Research, 7: 5083-5091.

Sunil, K., Singh, J.P., Bhadoria, B.K., Gupta, J.N. 2003. Evaluation of some indigenous fodder shrubs in semi-arid region of Bundelkhand. Range Management and Agroforestry, 24: 114-117.

Van Soest, P.J., Robertson, J.B., Lewis, B.A. 1991. Methods for dietary fibre, neutral detergent fibre in relation to animal nutrition. Journal of Dairy Science, 74: 3583-3597.

Xu, T., Zi, X., Li, M., Zhou, H., Hou, G. 2011. Nutritive value of several tropical legume shrubs in Hainan province of China. Journal of Animal and Veterinary Advances, 10: 1640-1648. 